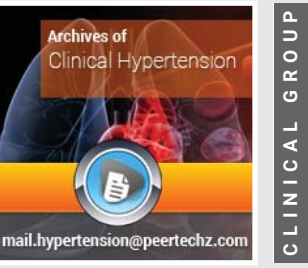

\title{
Horner's syndrome and fever: An unusual presentation of the giant cell arteritis
}

\section{Marzano* and PF Ballerini}

Department of Medicine, Town Hospital, Vittorio Veneto, Italy

Received: 23 December, 2019

Accepted: 30 December, 2019

Published: 31 December, 2019

*Corresponding author: L Marzano, MD, MSc, Department of Medicine, Town Hospital, Vittorio Veneto, Italy, E-mail: marzanoluigiMD@gmail.com

Keywords: Giant cell arteritis; Horner syndrome; Fever https://www.peertechz.com

\section{Check for updates}

\section{Summary}

The authors present a case of a histologically confirmed giant cell arteritis that presented unusually with fever and Horner's syndrome. The aetiology of the presenting features and the treatment choices are discussed.

\section{Background}

Giant Cell Arteritis (GCA), or temporal arteritis, is a systemic inflammatory vasculitis of unknown aetiology that occurs in older persons and can result in a wide variety of systemic, neurologic, and ophthalmologic complications [1]. A symmetrical polyneuropathy and mononeuritis both occur as manifestations of GCA [2-3], while the Horner's syndrome resulting from GCA is very rare. The case emphasises the need for physicians to promptly recognise and treat GCA to avoid long-term complications. In addition, we urge that GCA is considered as a diagnosis even when faced with uncommon presenting features

\section{Case presentation}

An 81-year-old, independent, Caucasian female, with no significant medical history, was admitted with a 4-week history of daily fevers of up to $38^{\circ} \mathrm{C}$ which had been unsuccessfully treated with antibiotics (amoxicillin/clavulanate and clarithromycin) and in last days presented a drooping of the right upper eyelid with a referred eye discomfort, fleeting diplopia and lost weight. Moreover, she referred to a headache note quickly responding to paracetamol intake, but that in the last week was more localized to the right. At clinical visit she had palpable temporal arteries but no visual or speech disturbance, limb weakness, neck stiffness or rash; nor did she have any scalp tenderness or jaw claudication. Physical examination was unremarkable. Neurological examination was unremarkable with normal motor and sensory systems and intact cranial nerve function with the exception of a miosis, apparent enophthalmos and ptosis of the right eyelid (Figure 1a).

Initial blood tests, blood and urine culture, chest x-ray, CTA of the chest, neck and brain, were normal apart from a raised erythrocyte sedimentation rate (ESR) of $66 \mathrm{~mm} / \mathrm{h}$ and $\mathrm{C}$ reactive protein (CRP) of $12 \mathrm{~g} / \mathrm{dl}$ with a normal levels of procalcitonin. The rheumatoid factor was very high $(207 \mathrm{Ui} / \mathrm{mL})$ in the absence of anti-citrullinated protein antibodies. Ophthalmology and ear, nose and throat reviews did not reveal any significant abnormalities or a cause for her symptoms. Visual acuity was 10/10 bilaterally. Neuro-ophthalmic examination confirmed a miosis and partial rightsized ptosis, while the optic nerves remained fully intact.

\section{Investigations}

Gadolinium-enhanced MRI of the spine and brain were normal. However, ESR and CRP were risen to $91 \mathrm{~mm} / \mathrm{h}$ and $8.8 \mathrm{mg} / \mathrm{dl}$, respectively. The diagnosis of Temporal Arteritis (TA) was considered according to American College of Rheumatology criteria [4], we performed a temporal artery biopsy and started on a 3-day course of intravenous methylprednisolone (1g/day).

After 3 days of intravenous steroid treatment, the cenesthesia was markedly improved, the fever had disappeared and the ESR and CRP were dropped to $51 \mathrm{~mm} / \mathrm{h}$ and $1.5 \mathrm{mg} / \mathrm{dl}$. However, the miosis and partial right-sided ptosis persisted. Histology of temporal artery biopsy returned a florid positive result for GCA (Figure 1b,c) 


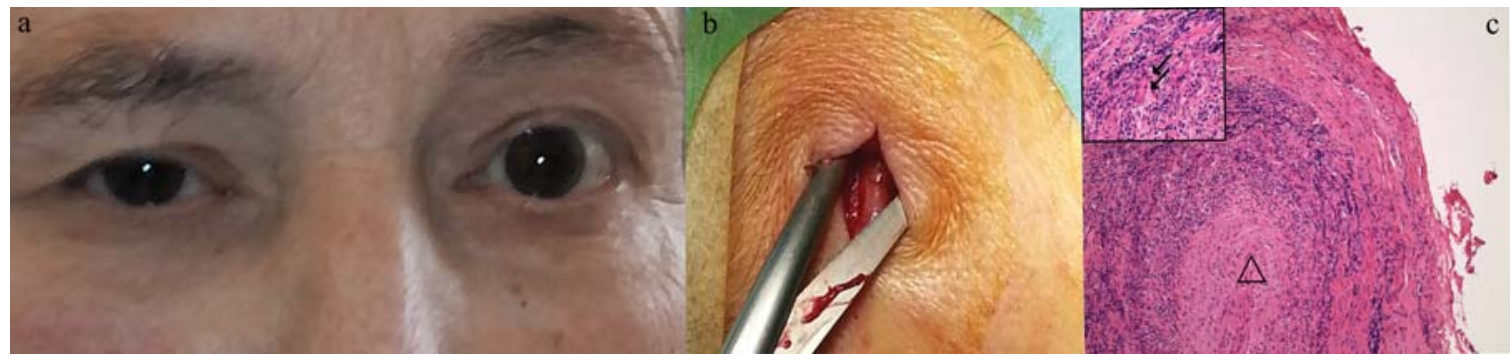

Figure 1: (a) Right Horner's syndrome. (b) Temporal arteritis at the time of biopsy. (c) The biopsy. Showing an acute arteritis with fibrinoid change, transmura inflammation until complete closure of the vascular lumen (triangle) and scattered giant cells within the media (arrows).

\section{Differential diagnosis}

Horner syndrome especially in the presence of persistent fever merits special consideration, since it may be indicative of compression by an apical bronchogenic carcinoma (Pancoast tumor), while in the presence of acute-onset, ipsilateral facial or neck pain may indicate carotid artery dissection.

The conditions to be considered in the differential diagnoses include the following: basal meningitis (eg, syphilis), basal skull tumors, cerebral vascular accident, demyelinating disease (eg, multiple sclerosis), lesions in the hypothalamus or medulla or intrapontine haemorrhage, neck trauma, pituitary tumor and syringomyelia, aneurysm or dissection of the aorta, central venous catheterization, limphadenopathy (eg, Hodgkin disease, leukemia, tuberculosis, or mediastinal tumors), lesions of the middle ear (eg, acute otitis media), Raeder syndrome (paratrigeminal syndrome) and cluster or migraine headache, herpes zoster.

\section{Treatment}

The initial high-dose corticosteroid therapy and steroid tapering regimen was established in accordance with the British Society of Rheumatology guidelines [5].

\section{Outcome and Follow-up}

After about 12 days of treatment the miosis had disappeared and ptosis of the right eyelid was improved but not resolved to the Ophthalmology and Neurology reviews. Currently, the patient is maintained on a reducing dose of oral steroid and has follow-up with rheumatology.

\section{Discussion}

GCA is the most common form of systemic vasculitis in adults that occurs in older persons and can result in a wide variety of systemic, neurologic, and ophthalmologic complications [6]. Horner's syndrome results from an interruption of the sympathetic nerve supply to the eye and is characterized by the classic triad of miosis, partial ptosis, and loss of hemifacial sweating and our patient clearly demonstrated the typical features of this rare syndrome.

The common lesions that cause Horner's syndrome interfere with preganglionic fibers as they course through the upper thorax. Virtually all lesions producing postganglionic sympathetic dysfunction are located intracranially or intraorbitally because the superior cervical ganglion is near the skull. Preganglionic Horner syndrome indicates a serious underlying pathology and is associated with a high incidence of malignancy. Postganglionic involvement has primarily benign causes (eg, usually a vascular headache) and to the best of our knowledge there is no documented case of such involvement with fever resistant to antibiotics in biopsy proven GCA

The absence of brainstem and spinal cord signs and a normal brain MRI argues against a preganglionic location. Ophthalmoplegia in GCA is commonly attributed to neuronal damage. There has been debate among authors whether ocular muscle ischaemia or nerve involvement is the primary pathological cause of the ophthalmoparesis [7-9]. The complete recovery of miosis and ptosis, as seen in our patient, would suggest that permanent neuronal damage has not occurred and this uncommon clinical presentation of GCA could be attributed to ischaemia of the postganglionic nerves due to an arteritis of the vasa nervorum [10], but we did not perform imaging to prove such a theory that continues to be an interesting area for further research and discussion in neurologic complication of GCA.

It is likely that in patients with high levels of rheumatoid factor, the involvement of the vasa nervorum is earlier and more intense in the autonomic nervous system, as documented in patients with rheumatoid arthritis $[11,12]$. However, in our patient it is not possible at the moment to speculate about the involvement only of the preganglionic fibers of the right side only.

This is to our knowledge, the first reported clinical case with a GCA who presented with persistent fever and an acute postganglionic isolated Horner's syndrome.

We feel that the association of GCA and Horner's syndrome, taken together with that other rare reported clinical cases [1315], indicates an unusual manifestation of GCA, which has possibly been overlooked in the past.

\section{Learning points/take home messages}

$>$ Giant cell arteritis (GCA) may very rarely present with a persistent fever and Horner's syndrome.

$>$ It is important to consider the diagnosis of GCA even with an unusual presentation. 
Rapid initiation of steroids is needed in TA to prevent permanent ophthalmoplegia and blindness, with oral treatment being as efficacious as intravenous.

\section{Acknowledgements}

The authors would like to acknowledge Dr Edoardo Podestà e Dr Cecilia Comunian, the Rheumatologists; Dr Giorgio Mazzarolo, the Vascular Surgeon who performed temporal artery biopsy.

\section{Contributors}

CC has met the patient after the diagnosis and is involved in the follow-up. All the authors were involved in the writing and revision of the manuscript and followed the patient in the initial phase and diagnosed, along with rheumatologists, pathologist, ophthalmologist, neurologists and neuroradiologists.

\section{Patient consent}

Obtained.

\section{References}

1. Hoffman GS (2016) Giant Cell Arteritis. Ann Intern Med 165: ITC65-ITC80. Link: http://bit.ly/2RMPn4H

2. Russell RW (1959) Giant-cell arteritis. A review of 35 cases. Q J Med 28: 471 489. Link: http://bit.ly/37sSmWr

3. Warrell DA, Godfrey S, Olsen EGJ (1968) Giant-cell arteritis with peripheral neuropathy. Lancet 1010-1013. Link: http://bit.ly/30PQWmi

4. Hunder GG, Bloch DA, Michel BA, Stevens MB, Arend WP, et al. (1990) The American College of Rheumatology 1990 criteria for the classification of giant cell arteritis. Arthritis Rheum 33: 1122-1128. Link: http://bit.ly/30REF0I
5. Dasgupta B, Borg AF, Hassan N, Barraclough K, Bourke B, et al. BSR and BHPR guidelines for the management of giant cell arteritis. Rheumatology 49: 15941597. Link: http://bit.ly/36ruCkd

6. Hoffman GS (2016) Giant Cell Arteritis. Ann Intern Med 165: ITC65-ITC80 Link: http://bit.ly/2RMPn4H

7. Lazaridis C, Torabi A, Cannon S (2005) Bilateral third nerve palsy and temporal arteritis. Arch Neurol 62: 1766-1768. Link: http://bit.ly/30RX8Ku

8. Hamed LM, Guy JR, Moster ML, Bosley T (1992) Giant cell arteritis in the ocular ischaemic syndrome. Am J Opthalmol 113: 702-705. Link: http://bit.ly/36sWynM

9. Mehler MF, Rabinowich L (1988) The clinical neuro-ophthalmologic spectrum of temporal arteritis. Am J Med 85: 839-844. Link: http://bit.ly/37oev8s

10. Warrell DA, Godfrey S, Olsen EGJ (1968) Giant-cell arteritis with periphera neuropathy. Lancet 1: 1010-1013. Link: http://bit.ly/37rVHoy

11. Koopman FA, van Maanen MA, Vervoordeldonk MJ, Tak PP (2017) Balancing the autonomic nervous system to reduce inflammation in rheumatoid arthritis. J Intern Med 282: 64-75. Link: http://bit.ly/37q41oN

12. Saraswathi PV, Neelambikai N, Mahesh A, Govindarajan K(2013)Cardiovascular parasympathetic nervous system dysfunction in female rheumatoid arthritis patients. Indian J Physiol Pharmacol 57: 23-30. Link: http://bit.ly/2GixNQy

13. Boschi A, Vliers S, Lefebvre C (1995) Unusual manifestation of Horton's disease: apropos of 2 case reports. Bull Soc Belge Ophtalmol 259: 189-195. Link: http://bit.ly/2tGgEx

14. Shah AV, Paul-Oddoye AB, Madill SA, Jeffrey MN, Tappin AD (2007) Horner's syndrome associated with giant cell arteritis. Eye 21: 130-131. Link: http://bit.ly/36sDk1w

15. Arunagiri G, Santhi S, Harrington T (2006) Horner syndrome and ipsilateral abduction deficit attributed to giant cell arteritis. J Neuroophthalmol 26: 231 232. Link: http://bit.ly/30TDCNG

\section{Discover a bigger Impact and Visibility of your article publication with}

Peertechz Publications

\section{Highlights}

* Signatory publisher of ORCID

* Signatory Publisher of DORA (San Francisco Declaration on Research Assessment)

* Articles archived in worlds' renowned service providers such as Portico, CNKI, AGRIS, TDNet, Base (Bielefeld University Library), CrossRef, Scilit, J-Gate etc.

* Journals indexed in ICMJE, SHERPA/ROMEO, Google Scholar etc.

* OAI-PMH (Open Archives Initiative Protocol for Metadata Harvesting)

* Dedicated Editorial Board for every journal

* Accurate and rapid peer-review process

* Increased citations of published articles through promotions

* Reduced timeline for article publication

Submit your articles and experience a new surge in publication services (https://www.peertechz.com/submission).

Peertechz journals wishes everlasting success in your every endeavours.

Copyright: ( $) 2019$ Marzano L, et al. This is an open-access article distributed under the terms of the Creative Commons Attribution License, which permits unrestricted use, distribution, and reproduction in any medium, provided the original author and source are credited. 